\title{
In Vitro Investigation of the Effects of Imidacloprid on AChE, LDH, and GSH Levels in the L-929 Fibroblast Cell Line
}

\section{L929 Fibroblast Hücre Hattında İmidoklorit Etkisinin In Vitro Araştırılması}

\author{
(D) Çiğdem SEVIM¹, (D) Ali TAGHiZADEHGHALEHJOUGHi2, (D) Mehtap KARA2* \\ 1Istanbul University Faculty of Pharmacy, Department of Pharmaceutical Toxicology, İstanbul, Turkey \\ 2Atatürk University Veterinary Faculty, Department of Pharmacology and Toxicology, Erzurum, Turkey
}

\begin{abstract}
Objectives: There are several types of pesticides to control pests and several new types coming into use that could be less toxic compared to the old ones. Pesticide-induced oxidative stress, which is one of the main mechanisms of toxicity, is the research area focused most on over the last decade. There are several different studies in the literature on whether pesticide exposure induces oxidative stress parameter-mediated toxicity. Pesticide-induced oxidative stress level depends on the biochemical features of mammalian systems. Imidacloprid is a neonicotinoid pesticide in wide use that is considered safe; however, it has been reported in different studies that it may cause changes in oxidative stress parameters.

Materials and Methods: We investigated the dose- and time-dependent effects of imidacloprid on acetylcholinesterase (AChE), lactate dehydrogenase (LDH), and glutathione (GSH) levels in the L-929 fibroblast cell line. The effects of 1-500 $\mu \mathrm{g}$ imidacloprid dose range on AChE, GSH, and LDH were investigated.

Results: LDH levels were significantly increased dose dependently in the 250 and $500 \mathrm{ng}$ imidacloprid groups compared to the control group. GSH levels nonsignificantly decreased dose dependently and GSH levels were lower in the $500 \mathrm{ng}$ imidacloprid group compared to the control group. There were no significant differences between the groups in AChE levels.

Conclusion: These results indicated that high doses of imidacloprid may induce oxidative stress in fibroblast cells.
\end{abstract}

Key words: Imidacloprid, L-929 cell line, oxidative stress, AChE

ÖZ

Amaç: Haşereleri kontrol altına almak için çeșitli pestisit türleri ve eskilere kıyasla daha az toksik olan yeni tür pestisitler kullanıma giriyor. Toksisitenin ana mekanizmalarından biri olan pestisit kaynaklı oksidatif stres, son on yılda en çok odaklanan araștırma alanıdır. Literatürde pestisit maruziyetinin oksidatif stres parametresi aracılı toksisiteyi indüklemesine ilișkin farklı çalışmalar mevcuttur. Pestisit kaynaklı oksidatif stres seviyesi, memeli sistemlerinin biyokimyasal özelliklerine bağlıdır. İmidakloprid, güvenli olduğu düșünülen, yaygın olarak kullanılan bir neonikotinoid pestisittir; ancak oksidatif stres parametrelerinde değişikliklere neden olabileceği farklı çalışmalarda bildirilmiştir.

Gereç ve Yöntemler: Bu çalışmada doza ve zamana bağımlı olarak imidaklopridin L-929 fibroblast hücrelerinde AChE, laktat dehidrogenaz (LDH) ve glutatyon (GSH) düzeyleri üzerine etkisini inceledik. 1-500 $\mu$ g imidakloprid dozlarının asetilkolinesteraz, glutatyon ve laktat dehidrojenaz düzeyleri üzerine etkileri araştırıldı.

Bulgular: 250 ve 500 ng dozda imidaklopridin LDH seviyelerini, kontrol grubuna kıyasla anlamlı olarak artırdığı tespit edildi. GSH seviyelesinin dozdan bağımsız olarak 500 ng imidakloprid dozunda kontrol grubuna kıyasla anlamlı olarak azaldığı tespit edildi. Asetilkolinesteraz seviyeleri arasında anlamlı bir fark gözlenmedi.

Sonuç: Bu sonuçlara göre yüksek doz imidakloprid maruziyeti fibroblast hücrelerinde oksidatif stres parametrelerini uyarabileceği gözlemlenmiştir. Anahtar kelimeler: İmidakloprid, L-929 hücre hattı, oksidatif hasar, AChE

*Correspondence: E-mail: matost@gmail.com, Phone: +90 5073492478 ORCID-ID: orcid.org/0000-0001-7764-5593

Received: 30.05.2019, Accepted: 29.08.2019

๑Turk J Pharm Sci, Published by Galenos Publishing House. 


\section{INTRODUCTION}

Pesticides are mixtures of substances used to prevent, control, or reduce harmful organisms. Pesticides include active substances and filling material that facilitate usage and increase the effect of their active substances. Commercially available drugs are manufactured and launched to market in mixed form with filling material. In Turkey 2,500 tons of pesticides are used every year. ${ }^{1-3}$

It has been speculated that neonicotinoid pesticides exhibit much lower toxic effects on mammals than on insects and therefore can replace organophosphates and carbamate insecticides. Neonicotinoid pesticides are a high risk for humans as they are often used not only in agricultural applications but also in the removal of domestic pests. Neonicotinoid pesticides show their selective toxic effects on insects via nicotinic acetylcholine receptors. Imidacloprid, which is a member of a new neuroactive neonicotinoid insecticide class, is a commonly used insecticide around the world as well as in Turkey. It has been reported that 120 countries have commonly used imidacloprid since 1990, when it was first introduced commercially. It has been reported that imidacloprid's oral LD50 values for rats were 380-650 $\mathrm{mg} / \mathrm{kg}$ body weight and for mice $130-170 \mathrm{mg} / \mathrm{kg}$ body weight. Under aerobic conditions, imidacloprid is an environmentally persistent chemical with a 3-year half-life, which increases its risk. ${ }^{4-7}$

Pesticide-induced oxidative stress has been the focus of toxicological research over the last decade as a possible mechanism of toxicity. Several studies have been conducted to determine whether oxidative stress in humans or animals is caused by various agents in this group and is related to their toxic effects. ${ }^{8,9}$ It has been reported in different studies that imidacloprid induced oxidative stress parameters' imbalance in different organisms in vitro and in vivo; ${ }^{10-17}$ however, there are no studies on imidacloprid's oxidative imbalance effects on fibroblast tissue in the literature.

In the present study we aimed to investigate the in vitro effects of imidacloprid on acetylcholinesterase (AChE), lactate dehydrogenase (LDH), and glutathione (GSH) levels in the L929 fibroblast cell line.

\section{MATERIALS AND METHODS}

\section{Chemicals}

Dulbecco's Modified Eagle's Medium (DMEM), fetal bovine serum (FBS), phosphate-buffered saline (PBS), penicillin streptomycin solution, and trypsin-EDTA solution were purchased from Sigma-Aldrich Co. (St. Louis, MO, USA). The AChE assay kit (Fluorometric Red, ab138873), LDH assay kit (Fluorometric, ab197000), and GSH assay kit (Fluorometric, ab65322) were purchased from Abcam (Cambridge, UK). The L929 cell line (CRL-6364) was purchased from the American Type Culture Collection (ATCC, VA, USA). The imidaclopridbased herbicide (GORTCA FS 600) was purchased from Safa Tarım Ltd. (Turkey) and contained pure imidacloprid (CAS number: 138261-41-3, product code: 0210-207).

\section{Cell culture and treatments}

All experiments on L929 were performed within 20 passages. The cells were grown with DMEM containing 10\% FBS and $1 \%$ penicillin-streptomycin-amphotericin $B$ in a humidified incubator supplied with $5 \%$ of $\mathrm{CO}_{2}$ at $37{ }^{\circ} \mathrm{C}$. Before the treatments were conducted, the cells were cultured for $24 \mathrm{~h}$ to ensure attachment.

The L-929 cells were incubated with imidacloprid dissolved in $100 \%$ of dimethyl sulfoxide (DMSO) and diluted with medium to the desired concentrations as $500 \mu \mathrm{g}, 250 \mu \mathrm{g}, 125 \mu \mathrm{g}, 50 \mu \mathrm{g}, 25$ $\mu \mathrm{g}, 5 \mu \mathrm{g}$, and $1 \mu \mathrm{g}$. Studies reported that cytotoxicity is observed at concentrations higher than $500 \mu \mathrm{g} / \mathrm{mL}$. In the present study a high concentration of imidacloprid was determined as $500 .{ }^{18}$ Vehicle control cells received equal volumes of DMSO (0.5\%) as the treatment for $24 \mathrm{~h}$. LDH, GSH, and AChE assays were performed after $24 \mathrm{~h}$ of exposure.

\section{Lactate dehydrogenase and glutathione parameters}

$\mathrm{LDH}$ is a cytosolic enzyme and the measurement of its leakage to the extracellular matrix due to cell membrane damage is an indicator of cell membrane integrity loss and oxidative stress. ${ }^{19}$

For this purpose, the L-929 cells were plated in 96-well plates at $1 \times 10^{4}$ cells/well and grown for $24 \mathrm{~h}$. Following the cell treatments, the LDH release in supernatants due to membrane damage was quantified using a rat LDH ELISA kit (Cat. number: E-EL-R2547) in accordance with the manufacturer's protocol. To each well was added $100 \mu \mathrm{L}$ of standard or sample, followed by incubation for $90 \mathrm{~min}$ at $37^{\circ} \mathrm{C}$. After the liquid was removed, $100 \mu \mathrm{L}$ of Biotinylated detection Ab was added, followed by incubation for $1 \mathrm{~h}$ at $37^{\circ} \mathrm{C}$. After aspiration and washing 3 times, $100 \mu \mathrm{L}$ of horseradish peroxidase (HRP) conjugate was added, followed by incubation for $15 \mathrm{~min}$ at $37^{\circ} \mathrm{C}$. After more aspiration and washing 5 times, $90 \mu \mathrm{L}$ of substrate reagent was added, followed by incubation for $15 \mathrm{~min}$ at $37^{\circ} \mathrm{C}$. When $50 \mu \mathrm{L}$ of stop solution was added, it was read at $450 \mathrm{~nm}$ using a micro-plate reader (Biotek Epoch, USA).

GSH is an important molecule for the cellular antioxidant system and under oxidative stress conditions GSH level decreases. The L-929 cells were cultured in $25-\mathrm{cm}^{2}$ flasks to determine GSH levels. Following exposure of cells to imidacloprid, $1 \times 10^{6}$ cells were harvested in $1 \mathrm{~mL}$ of PBS and were homogenized by sonication, and the GSH content of the L-929 cells was determined using the GSH ELISA kit (Cat. number: E-EL-0026) to assay human GSH following the manufacturer's procedure and referred to as $\mu \mathrm{mol} / \mathrm{g}$ protein. To each well was added $50 \mu \mathrm{L}$ of standard or sample and then immediately $50 \mu \mathrm{L}$ of Biotinylated detection $\mathrm{Ab}$ was added, followed by incubation for $45 \mathrm{~min}$ at $37^{\circ} \mathrm{C}$. After aspiration and washing 3 times, $100 \mu \mathrm{L}$ of HRP conjugate was added, followed by incubation for $30 \mathrm{~min}$ at $37^{\circ} \mathrm{C}$. After aspiration and washing 5 times, $90 \mu \mathrm{L}$ of substrate reagent was added, followed by incubation for $15 \mathrm{~min}$ at $37^{\circ} \mathrm{C}$. When $50 \mu \mathrm{L}$ stop solution was added, it was read at $450 \mathrm{~nm}$ using a micro-plate reader (Biotek Epoch, USA). 


\section{Acetylcholinesterase assay}

AChE is strikingly distributed in the cell-substrate interface of radiated and migrating fibroblasts (morphoregulation by AChE in fibroblasts and astrocytes) and it helps us to understand how the nervous system works. The L-929 cells were cultured in $25-\mathrm{cm}^{2}$ flasks to determine AChE levels. Following exposure of cells to imidacloprid, $1 \times 10^{6}$ cells were harvested in $1 \mathrm{~mL}$ of PBS and were homogenized by sonication, and the AChE content of L-929 cells was determined using the AChE assay kit (colorimetric, Cat. number: ab138871). To each well of AChE standard, blank control, and test samples was added $50 \mu \mathrm{L}$ of $\mathrm{AChE}$ reaction mixture to make the total AChE assay volume 100 $\mu \mathrm{L} /$ well, followed by incubation for $30 \mathrm{~min}$ at room temperature. Increased fluorescence monitored absorbance optical density at $140 \mathrm{~nm}$ with a micro-plate reader (Biotek Epoch, USA).

\section{Statistical analysis}

All the experiments were performed as three replicates and the results were presented as the mean \pm standard deviation. The statistical comparisons were evaluated using One-Way ANOVA followed by Tukey's test for post hoc analysis, and the statistical significance was set at $p<0.05$ (SPSS, version 21.0, USA).

\section{RESULTS}

The LDH results of imidacloprid exposure on L929 cells are shown in Figure 1. We observed that LDH levels increased dose dependently, and 250 and 500 ng imidacloprid increased LDH levels significantly compared to the control group. GSH results of imidacloprid exposure on L929 cells are shown in Figure 2. GSH levels nonsignificantly decreased dose dependently and GSH levels decreased in the $500 \mathrm{ng}$ imidacloprid group compared to the control group. AChE results of imidacloprid exposure on L929 cells are shown in Figure 3. There were no significant differences between the groups, but the AChE level nonsignificantly decreased in the $125 \mathrm{ng}$ group.

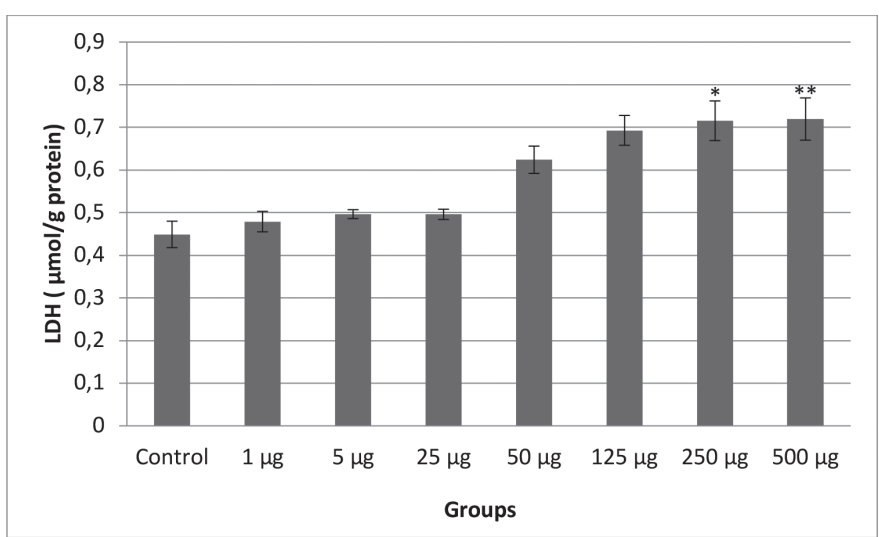

Figure 1. LDH level in L-929 cells with imidacloprid exposure LDH: Lactate dehydrogenase

\section{DISCUSSION}

Neonicotinoids are pesticides popular worldwide whose use has increased since 2000. Neonicotinoids exert their

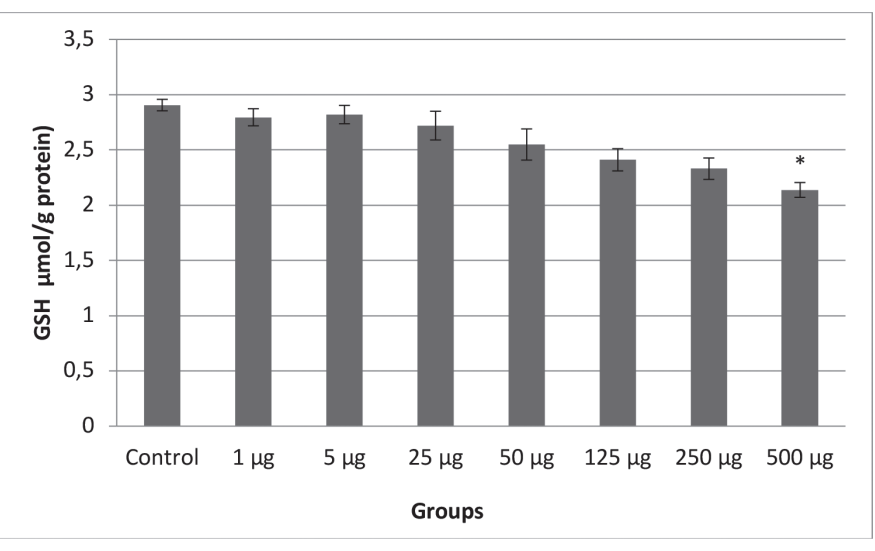

Figure 2. GSH level in L-929 cells with imidacloprid exposure GSH: Glutathione

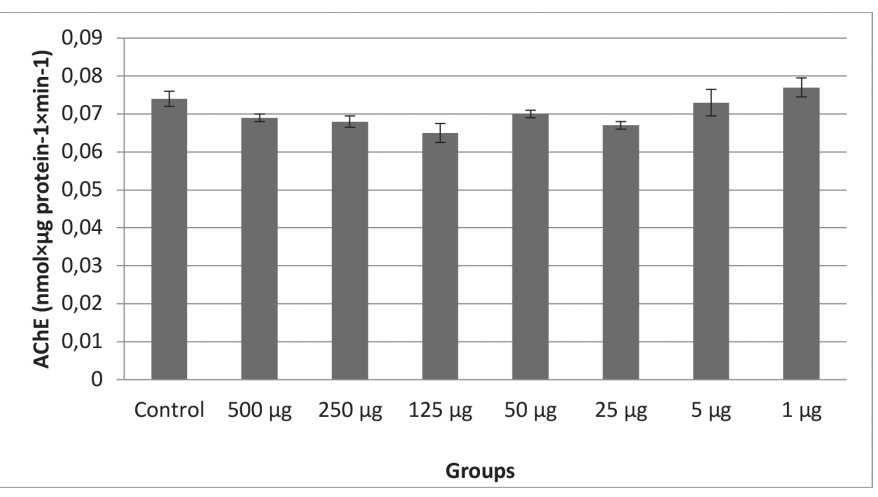

Figure 3. AChE level in L-929 cells with imidacloprid exposure AChE: Acetylcholinesterase

effects on insects by cellular nAChR mechanism. ${ }^{20,21}$ In recent years, neonicotinoids have taken the place of pyrethroid, organophosphorus, and carbamate insecticides..$^{22}$ It is thought that they are a safe pesticide group for nontarget species; however, there are several recent studies in the literature about different toxic effects of neonicotinoids on nontarget organisms. ${ }^{23,24}$

The stable cytoplasmic enzyme LDH is an important biomarker for oxidative stress, apoptosis, necrosis, and other forms of cellular damage, expressed in all cells and rapidly released when the plasma membrane is damaged. In a study conducted in 2018, Kumar et al. ${ }^{25,26}$ showed that LDH level increased with cellular damage, in accordance with our study. Abu Zeid et al. ${ }^{27}$ reported that imidacloprid exposure in the Rock pigeon (Columba livia domestica) resulted in a significant increase in plasma LDH levels in high dose $(6 \mathrm{mg} / \mathrm{kg}$ ) and median dose (3 $\mathrm{mg} / \mathrm{kg}$ ) imidacloprid groups; however, there were no significant increase in the low dose $(2 \mathrm{mg} / \mathrm{kg}$ ) group compared to the control group. Plasma AChE's enzyme activities in all imidacloprid dose groups significantly increased compared to the control group. Lonare et al. ${ }^{28}$ demonstrated that, 45 and $90 \mathrm{mg} / \mathrm{kg}$ body weight oral exposure of imidacloprid for 28 days significantly decreased AChE level in rats' erythrocytes. In addition, the brain AChE activity in rats in the imidacloprid treatment groups was decreased in a dose dependant manner compared to the control group. They also demonstrated that LDH levels increased and 
GSH levels decreased significantly imidacloprid treated groups in different tissues of rats. Imidacloprid exposure increased the GSH and AChE activities in Chinese rare minnows' brain. This result indicates that imidacloprid has no effect on Chinese rare minnows." It has been demonstrated that imidacloprid has neurotoxic effects through AChE inhibition and induces oxidative stress in rainbow trout brain tissue. ${ }^{29}$ Moreover, imidacloprid exposure significantly decreased AChE levels in the plasma and brain of 10 and $20 \mathrm{mg} / \mathrm{kg}$ treated female rats. ${ }^{30}$ In another study 24-h $20 \mathrm{mg} / \mathrm{kg}$ imidacloprid administration decreased AChE activity approximately $22 \%$ in the brain and $28 \%$ in red blood cells. ${ }^{31}$

\section{CONCLUSION}

Studies about imidacloprid's effects on AChE, LDH, and GSH express controversial results, which may be related to different study conditions such as species variety, exposure time variety, in vitro and in vivo conditions, and different doses. There are studies that include oxidative stress inducing effects of imidacloprid with different species in the literature; however, the underlying mechanism is not elucidated yet. Further studies are needed to clarify the toxic effects of neonicotinoids, especially imidacloprid, in different species and in different tissues.

Conflicts of interest: No conflict of interest was declared by the authors. The authors alone are responsible for the content and writing of the paper.

\section{REFERENCES}

1. Cha YS, Kim H, Lee Y, Choi EH, Kim HI, Kim OH, Cha KC, Lee KH, Hwong SO. The relationship between serum ammonia level and neurologic complications in patients with acute glufosinate ammonium poisoning: A prospective observational study. Hum Exp Toxicol. 2018;37:571-579.

2. Park S, Kim DE, Park SY, Gil HW and Hong SY. Seizures in patients with acute pesticide intoxication, with a focus on glufosinate ammonium. Hum Exp Toxicol. 2018;37:331-337.

3. Calas AG, Perche O, Richard O, Perche A, Pâris A, Lauga F, Herzine A, Palomo J. Ardourel MY, Menuet A, Mortaud S, Pichon J, MontécotDubourg C. Characterization of seizures induced by acute exposure to an organophosphate herbicide, glufosinate-ammonium. Neuroreport. 2016;27:532-541.

4. Kavvalakis MP, Tzatzarakis MN, Theodoropoulou EP, Barbounis EG, Tsakalof AK, Tsatsakis AM. Development and application of LC-APCI-MS method for biomonitoring of animal and human exposure to imidacloprid. Chemosphere. 2013;93:2612-2620.

5. Kim J, Park Y, Yoon KS, Clark JM, Park Y. Imidacloprid, a neonicotinoid insecticide, induces insulin resistance. J Toxicol Sci. 2013;38:655-660.

6. Park Y, Kim Y, Kim J, Yoon KS, Clark J, Lee J, Park Y. Imidacloprid, a neonicotinoid insecticide, potentiates adipogenesis in 3T3-L1 adipocytes. J Agric Food Chem. 2013;61:255-259.

7. Tomizawa M, Casida JE. Imidacloprid, thiacloprid, and their imine derivatives up-regulate the alpha 4 beta 2 nicotinic acetylcholine receptor in M10 cells. Toxicol Appl Pharmacol. 2010;169:114-120.
8. Etemadi-Aleagha A, Akhgari M, Abdollahi M. A brief review on oxidative stress and cardiac diseases. Mid East Pharm. 2002;10:8-9.

9. Abdollahi M, Ranjbar A, Shadnia S, Nikfar S, Rezaie A. Pesticides and oxidative stress: a review. Med. Sci. Monit. 2004:10:141-147.

10. Wang $Y$, Han $Y, X u$ P, Guo B, Li W, Wang X. The metabolism distribution and effect of imidacloprid in chinese lizards (Eremias argus) following oral exposure. Ecotoxicol Environ Saf. 2018;165:476-483.

11. Tian X, Yang W, Wang D, Zhao Y, Yao R, Ma L, Ge C, Li X, Huang Z, $\mathrm{He} L$, Jiao W, Lin A. Chronic brain toxicity response of juvenile Chinese rare minnows (Gobiocypris rarus) to the neonicotinoid insecticides imidacloprid and nitenpyram. Chemosphere. 2018;210:1006-1012.

12. Njattuvetty Chandran N, Fojtova D, Blahova L, Rozmankova E, Blaha L. Acute and (sub) chronic toxicity of the neonicotinoid imidacloprid on Chironomus riparius. Chemosphere. 2018;209:568-577.

13. Shakir SK, Irfan S, Akhtar B, Rehman SU, Daud MK, Taimur N, Azizullah A. Pesticide-induced oxidative stress and antioxidant responses in tomato (Solanum lycopersicum) seedlings. Ecotoxicology. 2018;27:919935.

14. Özdemir $\mathrm{S}$, Altun $\mathrm{S}$ and Arslan $\mathrm{H}$. Imidacloprid exposure cause the histopathological changes, activation of TNF- $\alpha$, iNOS, 8-OHdG biomarkers, and alteration of caspase 3, iNOS, CYP1A, MT1 gene expression levels in common carp (Cyprinus carpio L.). Toxicol Rep. 2017;27:125-133.

15. Wang X, Anadón A, Wu Q, Qiao F, Ares I, Martínez-Larrañaga MR, Yuan Z, Martínez MA. Mechanism of neonicotinoid toxicity: impact on oxidative stress and metabolism. Annu Rev Pharmacol Toxicol. 2018;6:471-507.

16. Kapoor U, Srivastava MK, Bhardwaj S, Srivastava LP. Effect of imidacloprid on antioxidant enzymes and lipid peroxidation in female rats to derive its No Observed Effect Level (NOEL). J Toxicol Sci. 2010;35:577-581.

17. International Programme on Chemical Safety Toxicological evaluations: Imidacloprid, 2001; http://www.inchem.org/documents/jmpr/ jmpmono/2001pr07.htm, 2011.

18. California Environmental Protection Agency/Department of Pesticide Regulation; Summary of Toxicology Data, Imidacloprid (138261-41-3) p. 5-6 (May 24, 1993, Revised November 18, 2013). Available from, as of January 15, 2016.

19. Jovanovic P, Zoric L, Stefanovic I, Dzunic B, Djordjevic-Jocic J, Radenkovic M, Jovanovic M. Lactate dehydrogenase and oxidative stress activity in primary open-angle glaucoma aqueous humour. Bosn J Basic Med Sci. 2010;10:83-88.

20. Casida JE and Durkin KA Neuroactive insecticides: targets, selectivity, resistance, and secondary effects. Annu Rev Entomol. 2013;58:99-117.

21. Wood TJ, Goulson D. The environmental risks of neonicotinoid pesticides: a review of the evidence post Environ Sci Pollut Res Int. 2017;24:1728517325 .

22. Tankiewicz M, Fenik J and Biziuk M. Determination of organophosphorus and organonitrogen pesticides in water samples. Trac Trends Anal Chem. 2010;29:1050-1063.

23. Tennekes HA, Sanchez-Bayo F. Time-dependent toxicity of neonicotinoids and other toxicants: implications for a new approach to risk assessment J Environ Anal Toxicol. 2011;S4:1-8.

24. Whitehorn PR, O'connor S, Wackers FL, Goulson D. Neonicotinoid pesticide reduces bumble bee colony growth and queen production. Science. 2012;336:351-352. 
25. Shi DY, Xie FZ, Zhai C, Stern JS, Liu Y and Liu SL.The role of cellular oxidative stress in regulating glycolysis energy metabolism in hepatoma cells. Mol Cancer. 2003;5:32.

26. Kumar P, Nagarajan A and Uchil PD 2018 Analysis of Cell Viability by the Lactate Dehydrogenase Assay. Cold Spring Harb Protoc. 6 pdb. prot095497.

27. Abu Zeid EH, Alam RTM, Ali SA, Hendawi MY. Dose-related impacts of imidacloprid oral intoxication on brain and liver of rock pigeon (Columba livia domestica), residues analysis in different organs. Ecotoxicol Environ Saf. 2018;5:60-68.

28. Lonare M, Kumar M, Raut S, Badgujar P, Doltade S, Telang A. Evaluation of imidacloprid-induced neurotoxicity in male rats: a protective effect of curcumin. Neurochem. 2014;78:122-129.
29. Topal A, Alak G, Ozkaraca M, Yeltekin AC, Comaklı S, Acıl G, Kokturk $M$. Atamanalp M. Neurotoxic responses in brain tissues of rainbow trout exposed to imidacloprid pesticide: Assessment of 8-hydroxy2-deoxyguanosine activity, oxidative stress and acetylcholinesterase activity. Chemosphere. 2017;175:186-191.

30. Vohra P, Khera KS, Sangha GK. Physiological, biochemical and histological alterations induced by administration of imidacloprid in female albino rats. Pestic Biochem Physiol. 2014;110:50-56.

31. Kapoor U, Srivastava MK, Trivedi P, Garg V, Srivastava LP. Disposition and acute toxicity of imidacloprid in female rats after single exposure. Food Chem Toxicol. 2014;68:190-195. 